\title{
Эмиссия света двумерными островками дисульфида молибдена
}

\author{
А.В. Марченко ${ }^{1,2}$, А.Г. Милёхин ${ }^{1,2}$, Н.Н. Курусь ${ }^{1}$ \\ ${ }^{1}$ Институт физики полупроводников им.А.В. Ржсанова СО РАН, Новосибирск, \\ 630090, Лаврентьева, 13 \\ ${ }^{2}$ НГУ, Новосибирск, 630090, Пирогова, 1 \\ тел.8(383)316-60-54, эл. marchenko@g.nsu.ru
}

DOI 10.34077/RCSP2021-123

Двумерные халькогениды переходных металлов являются перспективными материалами для создания быстродействующих компонентов электронной техники и оптоэлектронных приборов. Особый интерес среди данного класса материалов представляет двумерный дисульфид молибдена $\left(\mathrm{MoS}_{2}\right)$, обладающий уникальными электронными и оптическими свойствами. Так, при уменьшении толщины пленки дисульфида молибдена до нескольких монослоёв происходит изменение его электронной зонной структуры, что проявляется в изменениях спектров комбинационного рассеяния света (КРС) и фотолюминесценции (ФЛ). Таким образом, исследование взаимосвязи структурных и оптических свойств $\mathrm{MoS}_{2}$ является актуальной задачей.

Данная работа посвящена исследованию пространственного распределения интенсивности ФЛ и КРС треугольными островками двумерного $\mathrm{MoS}_{2}$ различной толщины, сформированными на поверхности кремния. Морфология поверхности изучалась с помощью атомно-силовой микроскопии (ACM). АCM изображение островков представлено на Рис.1а. Толщина островков меняется от 2 до 6 монослоев (1 монослой (МС)- 0.6 нм).

Построены карты распределения интенсивности ФЛ в области межзонных переходов (Рис. 1б). В спектрах ФЛ наблюдаются пики, соответствующие прямым и непрямым переходам. Показано, что интенсивность ФЛ обратно пропорциональна количеству монослоев $\mathrm{MoS}_{2}$ в островке. Изучены спектры KCР островками двумерного $\mathrm{MoS}_{2}$. Получены зависимости частот основных колебательных мод $\mathrm{MoS}_{2}\left(\mathrm{~A}_{1 \mathrm{~g}}\right.$ и $\left.\mathrm{E}_{2 \mathrm{~g}}\right)$ от толщины островка. Построены карты распределения интенсивности КРС островками (Рис. 1в). Показано, что интенсивность КРС максимальна для минимальной толщины образца (2MC).

Обнаружено усиление интенсивности КРС моды оптического фонона кремния в области расположения бислоя $\mathrm{MoS}_{2}$ (Рис. 1г). Выдвинута гипотеза об интерференционном механизме усиления КРС фононами Si.
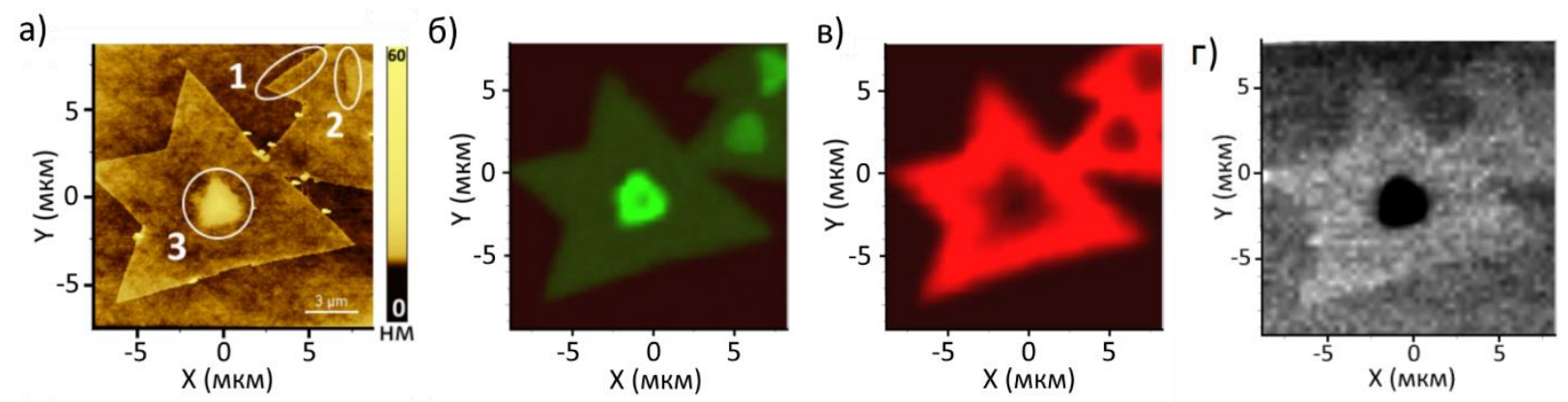

Рис.1 а) АCМ-изображение островка $\mathrm{MoS}_{2}$, б) Карта интенсивности фотолюминесценции слоями дисульфида молибдена, построенная в диапазоне 660-720 нм, в) Карта интенсивности $\mathrm{A}_{1 \mathrm{~g}}$ моды в спектре КРС слоями $\mathrm{MoS}_{2}$, построенная в диапазоне 401-415 см ${ }^{-1}$, г)- Карта интенсивности моды оптического фонона кремния, построенная в диапазоне 513-527 $\mathrm{cm}^{-1}$.

Работа выполнена при финансовой поддержке РФФИ в рамках научного проекта № 19-52-12041. 